\title{
Integrating Urban Agriculture and Stormwater Management in a Circular Economy to Enhance Ecosystem Services: Connecting the Dots
}

\author{
Tolessa Deksissa ${ }^{1, *}$, Harris Trobman ${ }^{2}$, Kamran Zendehdel ${ }^{2}$ and Hossain Azam ${ }^{3}$ \\ 1 Water Resources Research Institute, University of the District of Columbia, Washington, DC 20008, USA \\ 2 Center for Sustainable Development and Resilience, University of the District of Columbia, Washington, \\ DC 20008, USA; harris.trobman@udc.edu (H.T.); kamran.zendehdel@udc.edu (K.Z.) \\ 3 Department of Civil Engineering, University of the District of Columbia, Washington, DC 20008, USA \\ hossain.azam@udc.edu \\ * Correspondence: tdeksissa@udc.edu
}

Citation: Deksissa, T.; Trobman, H.; Zendehdel, K.; Azam, H. Integrating Urban Agriculture and Stormwater Management in a Circular Economy to Enhance Ecosystem Services: Connecting the Dots. Sustainability 2021, 13, 8293. https://doi.org/ $10.3390 /$ su13158293

Academic Editor: Tan Yigitcanlar

Received: 7 May 2021

Accepted: 21 July 2021

Published: 24 July 2021

Publisher's Note: MDPI stays neutral with regard to jurisdictional claims in published maps and institutional affiliations.

Copyright: (c) 2021 by the authors. Licensee MDPI, Basel, Switzerland. This article is an open access article distributed under the terms and conditions of the Creative Commons Attribution (CC BY) license (https:/ / creativecommons.org/licenses/by/ $4.0 /)$.

\begin{abstract}
Due to the rapid urbanization in the context of the conventional linear economy, the vulnerability of the urban ecosystem to climate change has increased. As a result, connecting urban ecosystem services of different urban land uses is imperative for urban sustainability and resilience. In conventional land use planning, urban agriculture (UA) and urban stormwater management are treated as separate economic sectors with different-disconnected-ecosystem services. Furthermore, few studies have synthesized knowledge regarding the potential impacts of integration of UA and stormwater green infrastructures (GIs) on the quantity and quality of urban ecosystem services of both economic sectors. This study provides a detailed analysis of the imperative question-how should a city integrate the developments of both urban agriculture and stormwater green infrastructure to overcome barriers while enhancing the ecosystem services? To answer this question, we conducted an extensive literature review. The results show that integrating UA with GIs can enhance urban food production while protecting urban water quality. This paper provides an initial context and mechanisms for future researchers and city planners regarding the manner in which the synergies between UA and stormwater GIs can create greater value for the wellbeing of urban ecosystems and resilience in the circular economy.
\end{abstract}

Keywords: aquaponic; bioretention; gardening; green roof; hydroponic; rainwater harvesting; urban resilience; urban runoff; urban sustainability; water quality

\section{Introduction}

As most of the world's population lives in urban areas, managing urban food insecurity and stormwater runoff is increasingly challenging globally due to the combined effects of climate change, rapid urban development, and fast population growth [1]. To address these challenges, sustainable urban agriculture (UA) and stormwater green infrastructures (GIs) have been considered to be alternative solutions to the conventional centralized agriculture practices and gray stormwater infrastructure [2-5]. Although sustainable urban agriculture can provide stormwater management benefits, it is often considered to be a separate sector from others, including stormwater management, in traditional urban land use planning and policy. Similarly, although stormwater green infrastructure may be able to produce food while managing stormwater, connecting the two economic sectors is not common, nor it is considered in current stormwater management policies.

Consequently, urban agriculture faces various barriers, including zoning limits, restricted land use planning, and a lack of funding for this non-integrated approach [6]. Although some of these challenges were addressed by the recently implemented 2018 US Farm Bill, sectoral-based and unsustainable urban farming practices may result in 
unintended consequences, such as increasing demand for water supply and degradation of urban freshwater resources [7-9]. As the global population is becoming increasingly urbanized, expanding urban agriculture using limited water supply can exacerbate problems related to the water security of cities. This requires innovative water resource management techniques, such as the use of non-traditional sources of water for urban agriculture, including stormwater runoff and reclaimed water. This indicates that the expansion in UA must occur in conjunction with advances in urban water resource management, including rainwater harvesting, stormwater retention, and water reuse [10]. In addition, UA and stormwater management must be integrated to enhance the ecological benefits of the two sectors in various ways, including via water reuse and resource recovery in a circular economy.

In conventional city planning and management, urban agriculture and stormwater management are operated by two departments with different primary objectives. Urban agriculture is mainly adopted for food production and aesthetic values, whereas stormwater management practices focus on managing stormwater quantity and quality. Since both food security and urban stormwater management are integral to most urban issues, addressing these challenges requires a holistic approach that creates synergy by enhancing ecosystem services.

To enhance urban social and environmental resilience, it is of paramount importance to integrate urban agriculture and stormwater green infrastructure. In addition, the number of publications that discuss stormwater or urban agriculture has increased since 2005 [11], but the literature related to the integration of the two systems to improve ecosystem services has remained limited. Finally, urban agriculture is becoming a popular practice in addressing urban food insecurity; however, the inability of urban agriculture to feed city populations as expected and land scarcity are current challenges and will remain so in the future. This study aimed to investigate both theoretical and practical means to address these challenges by fostering cross-collaboration among various urban land-use sectors. The objective of this study was to identify mechanisms by which cities should integrate UA and stormwater GIs developments to advance urban farming while enhancing the ecosystem services via the synergetic effects of the two systems. To address this specific objective, we conducted a detailed literature review on integrated UA and stormwater GIs systems, such as bio-retention cells and green roofs. The findings from this study provide adequate support for the integration of UA and stormwater GIs in building resilient cities and the circular economy.

The outcomes of the literature review are summarized in three categories. First, the findings related to best practices for urban agriculture and stormwater management circularity are discussed. Secondly, a significant part of the review is dedicated to evaluating the ecosystem-based approach of the available best practices, including the reduction or elimination of the waste externality of urban agriculture and stormwater management, resource recovery, reclaimed water reuse, stormwater retention and reuse, and associated ecosystem benefits, and to identify data or knowledge gaps and areas where further attention is warranted. Additionally, a review of possible mechanisms for integrating UA and stormwater GIs in a circular economy is summarized and compiled in a schematic diagram. Overall, the findings of this manuscript provide insights to the benefit of researchers, planners, and sustainability managers, for making urban environments more resilient.

\section{Materials and Methods}

In this study, an extensive literature search was conducted using digital databases, such as Science Direct, PubMed, Google Scholar, Web of Sciences, and ResearchGate to obtain information reported in English-only peer-reviewed studies published from 1997 until 2021. Table 1 illustrates the search terms and term description for articles identification and study screening. Based on inclusion and exclusion criteria, the synthesis was made based on Science Direct and ResearchGate as the only sources. Table 2 indicates inclusion and exclusion criteria. The review was performed using the combination of the primary 
terms or keywords: urban agriculture and stormwater green infrastructure, which can be stated as urban agriculture AND stormwater management OR circular economy OR green infrastructure OR bioretention cell OR stormwater pollution OR integrated water resources management OR integrated environmental management OR integrated landscape planning OR ecosystem service OR biobased circular economy. The search concluded on 30 April 2021.

Table 1. Review primary terms, term description, and search terms used for literature identification and screening.

\begin{tabular}{|c|c|c|c|}
\hline & Primary Term & Term Description & Search Terms \\
\hline \multirow{3}{*}{ Population } & Urban Agriculture & Economic sector of interest & $\begin{array}{l}\text { Urban farming, rooftop gardening, } \\
\text { hydroponic, aquaponic, composting, } \\
\text { and reclaimed water reuse }\end{array}$ \\
\hline & $\begin{array}{l}\text { Stormwater Green } \\
\text { Infrastructure }\end{array}$ & $\begin{array}{c}\text { Environmental management of } \\
\text { interest }\end{array}$ & $\begin{array}{l}\text { Bioretention cell; green roof; rain } \\
\text { garden; rainwater harvesting; urban } \\
\text { trees; stormwater gray infrastructure; } \\
\text { stormwater green Infrastructure }\end{array}$ \\
\hline & Ecosystem Services & $\begin{array}{l}\text { Environmental and socio-economic } \\
\text { benefits of UA and GI }\end{array}$ & $\begin{array}{l}\text { Ecosystem; Urban Ecosystem, } \\
\text { Ecosystem Services }\end{array}$ \\
\hline Outcome & Urban ecosystem services & $\begin{array}{l}\text { Environmental and socio-economic } \\
\text { benefits of interest }\end{array}$ & $\begin{array}{l}\text { Urban food production; stormwater } \\
\text { retention; water quality improvement; }\end{array}$ \\
\hline \multirow[t]{2}{*}{ Agent } & Water quality parameters & Water quality parameters of interest & $\begin{array}{l}\text { Total nitrogen; total phosphorus; total } \\
\text { suspended solids; trace metals }\end{array}$ \\
\hline & Fresh Produces & Urban food production of interest & Vegetable \\
\hline
\end{tabular}

Table 2. Inclusion and exclusion criteria.

\begin{tabular}{ccc}
\hline & Inclusion Criteria & Exclusion Criteria \\
\hline Study type & $\begin{array}{c}\text { Review articles; Research articles, conference abstract; book } \\
\text { chapters, discussion, editorial }\end{array}$ & Encyclopedia \\
\hline Language & English & Non-English \\
\hline Population & $\begin{array}{c}\text { Urban ecosystem services (Urban Agriculture, Urban } \\
\text { stormwater Management, Circular economy, Gray and } \\
\text { Green Infrastructure, Ecosystem) }\end{array}$ & Non-Urban ecosystem services \\
\hline Outcomes & $\begin{array}{c}\text { Sustainable urban agriculture practices as means to provide } \\
\text { food, reduce stormwater runoff or Green infrastructures as } \\
\text { ways to produce food, retain stormwater runoff, and } \\
\text { provide socio-economic benefits in a circular economy. }\end{array}$ & $\begin{array}{c}\text { Non-urban agricultural or non-urban } \\
\text { green stormwater infrastructure. }\end{array}$ \\
\hline Study Period & 1997-2021 & Pre-1997
\end{tabular}

The workflow of the literature search and screening is illustrated in Figure 1. In the databases, 78,021 article titles and abstracts published between 1997 and 2021 were identified by searching the two keywords-urban agriculture, and water management.

After excluding duplicates, we screened 25,554 abstracts and titles, which were then further screened to 197 studies excluding studies that do not contain these three termsurban agriculture, ecosystem, and stormwater GIs. Excluding non-peer-reviewed publications, 197 full-text studies were filtered for relevance and eligibility. Subsequently, 164 full-text studies were assessed for eligibility based on questions illustrated in Figure 2. Finally, 87 full-text studies were included in the quantitative and qualitative synthesis.

As illustrated in Figure 2, for each full-text publication included in the analysis, a similar search strategy to that presented by Ronchi [12] was adopted. In this example, six key questions were applied to evaluate each publication for the ecosystem-based integration of UA and stormwater GIs: 
1. What ecosystem services of UA and stormwater GIs are proposed for building synergy and integration of the two economic sectors (Q1)? This question is key to investigating how different stormwater GIs and UA contribute to the enhancement of ecosystem services while addressing urban food insecurity and urban stormwater management.

2. Have the ecosystems of UA and stormwater GIs been integrated (Q2)? This question is linked to question \#3 (Q3). Both questions were applied to further analyze and synthesize the integration of ecosystem services for different urban land uses.

3. Do the proposed theories or practices enhance the stormwater GIs and UA synergy (Q3)? This is a follow-up question to question \#2 (Q2) for an in-depth analysis of specific ecosystem services in view of building urban resilience.

4. What type of ecosystem services are provided by the proposed stormwater GIs to address urban food insecurity (Q4)? This question identifies alternative yet innovative approaches for integrating UA and stormwater GIs for the practical application of urban planning.

5. What type of ecosystem services are provided by urban agriculture to address issues related to urban stormwater management (Q5)? This additional question helps to examine the proposed findings in view of building urban resilience against the effects of extreme events due to climate change, e.g., flooding and water scarcity.

6. Are the mechanisms provided for the integration of the ecosystem services of UA and GIs for the circular economy and resilient cities (Q6)? This final question is for further analysis and exploration of alternative solutions to identify sustainable means of integrating the two economic sectors for future resilient cities while creating synergy between their ecosystem services.

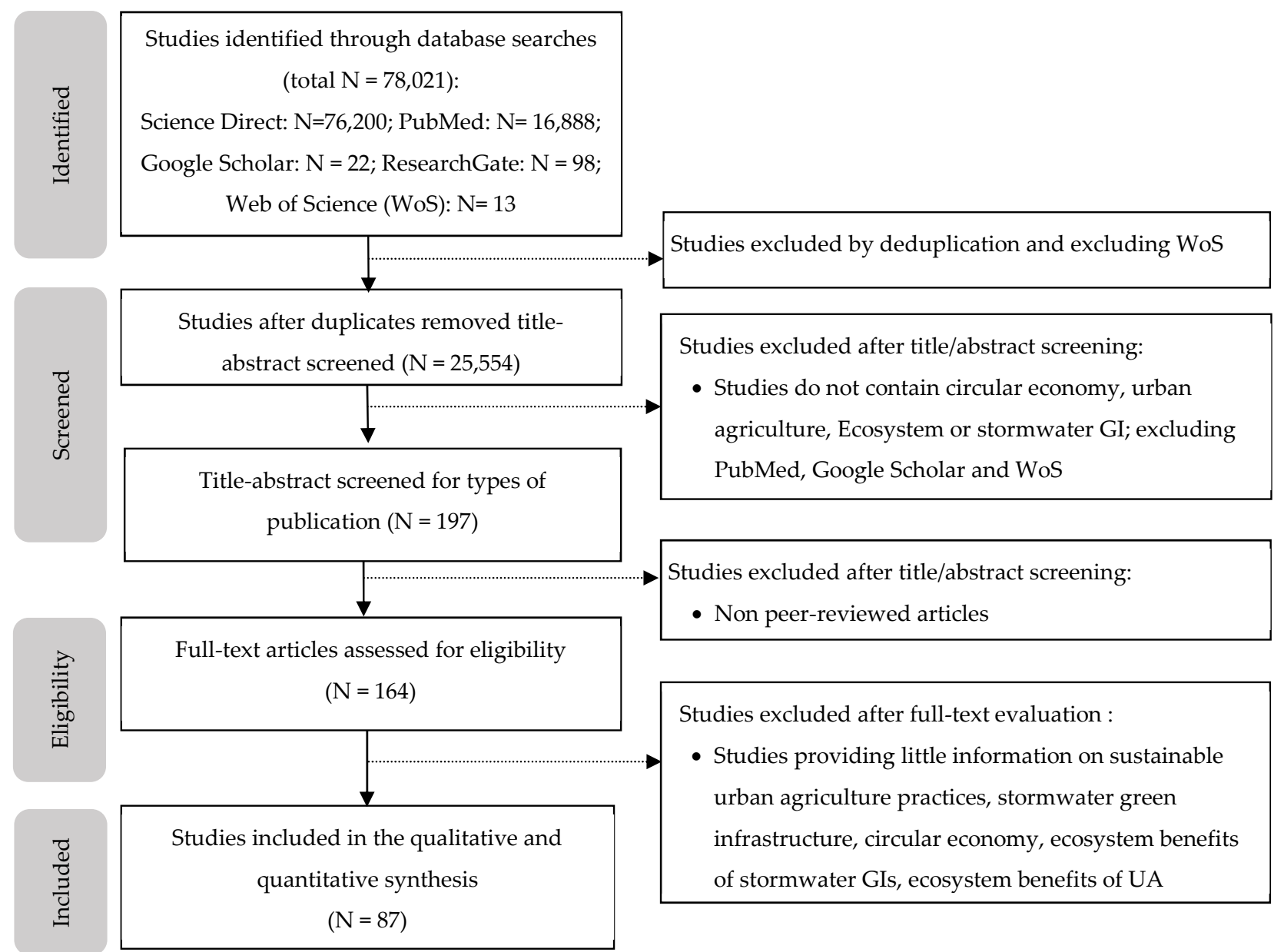

Figure 1. Flowchart of literature selection and screening. N represents the number of studies (articles); WoS = Web of Science. 
Search “Urban Agriculture” AND “Water Management” AND “Ecosystem” In ScienceDirect

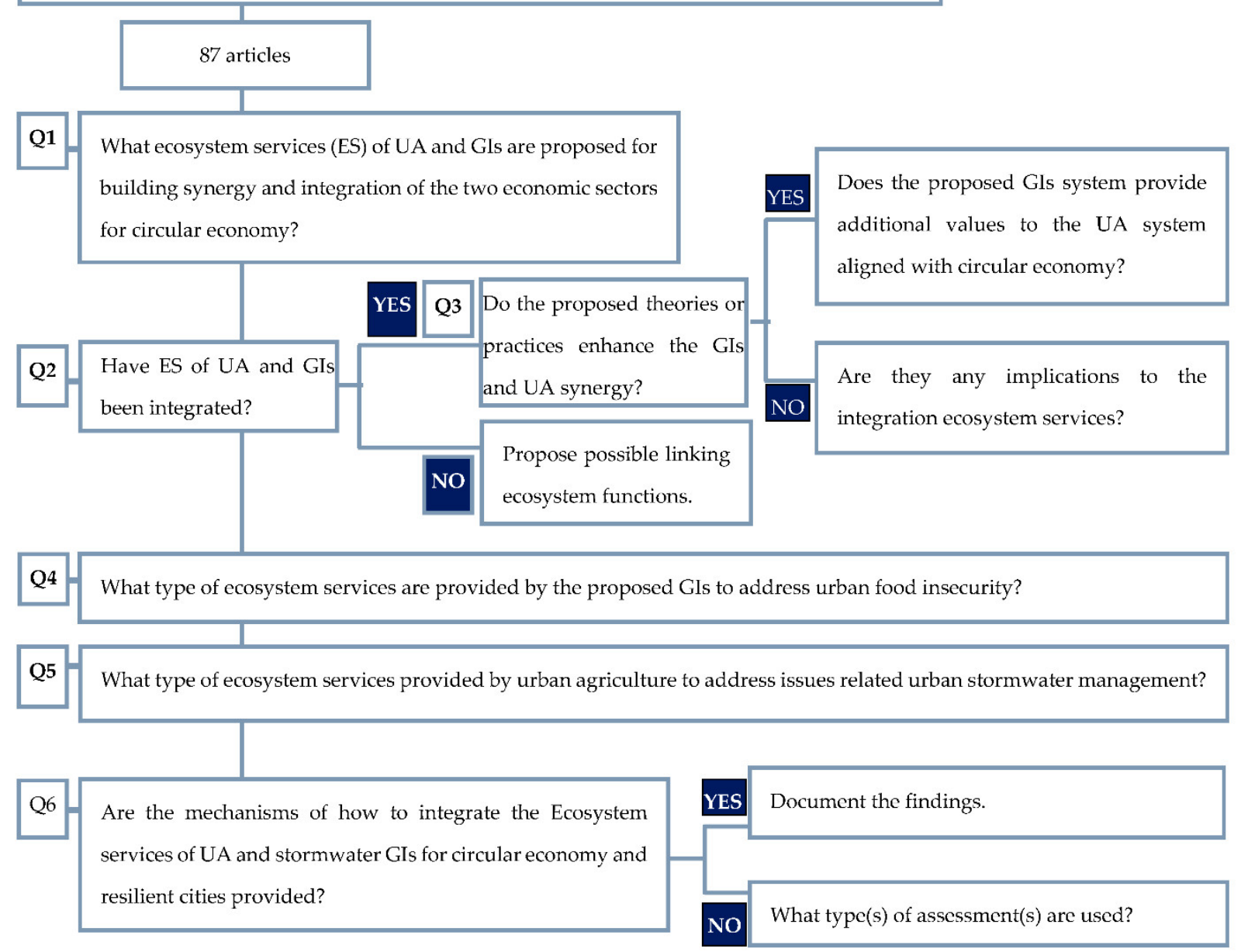

Figure 2. Questions applied for title screening and eligibility assessment.

\section{Results}

\subsection{Urban Resilience and Ecosystem Services}

The findings of this extensive literature study indicate that the resilience of urban ecosystems determines the sustainability and resilience of the urban environment. In other words, urban sustainability and resilience depend on the resilience of connected urban ecosystem services provided by different environmental and economic sectors [13]. Ecosystem services are benefits provided to humans through the transformations of resources into a flow of essential goods and services, such as provisional (food and water supply), cultural (recreation aesthetic values), regulating (water purification, erosion control), and supporting services (nutrient cycling, water cycling) [14]. The resilience of urban ecosystems depends on the ecosystem's biodiversity quality and quantity, including plants, animals, and microbial organisms [15]. Further, the diversity of urban organisms is the direct source of urban ecosystem services. It must be noted that an urban ecosystem is a human-modified ecosystem that requires continuous maintenance and management intervention to provide the intended services [16]. In planning urban green infrastructure development, the significance of the network and multifunctional connectivity of the green infrastructure is highlighted in recent studies [17,18].

This implies that strategic integration of ecosystem services is needed in urban planning related to urban stormwater management using green infrastructure. The need for 
strategic integration has been recognized to reduce inequality in the distribution of green infrastructure and associated ecosystem services in the disadvantaged socio-demographic and socio-economic areas of cities [19]. In addition, urban ecosystem functioning changes over space and time; this is also the case for the quality and quantity of ecosystem services, in addition to their demand and production [20]. Many researchers have recognized the importance of careful consideration of ecosystem services in urban planning, design, policy, and management $[18,21,22]$. Nevertheless, there is a lack of studies about the integration of expanding urban farming with stormwater green infrastructure in a circular economy in a manner that maintains nutrient and water circularity while providing synergetic effects of ecosystem services. In this study, we explored means of enhancing locally produced ecosystem services, such as the provision of fresh food and supporting services of stormwater retention and water purification, through the integration of sustainable urban agriculture and stormwater green infrastructure. In sustainable cities with a circular economy, assessing the need and mismatch of ecosystem services must be considered in urban planning and management. This shows the importance of identifying an approach to the strategic integration of urban agriculture and stormwater management.

\subsection{Urban Agriculture in a Circular Economy}

Sustainable urban agriculture can play a significant role in the circular economy and circular cities in various ways. For example, sustainable urban agriculture provides foods and fibers to the city while reducing stormwater runoff and the combined overflow of sewers in a circular economy. Sustainable urban agriculture is considered to be a sustainable solution to address not only urban food insecurity, but also to reduce stormwater runoff [23]. In addition, converting impervious areas to urban gardens reduces surface runoff and flooding [2]. Finally, rainwater harvesting can be used to supplement urban irrigation water demand [24-26]. Due to this ecological benefit, urban agriculture is expanding and is considered to be a form of green infrastructure [27,28].

Sustainable urban agriculture is consistent with circular economy principles. The circular economy requires the utilization and reuse of natural resources and the release of by-products into the environment after treatment of waste. Sustainable urban agriculture practices include environmental wellbeing and social equity while benefiting the ecosystem. In these sustainable practices, many researchers have documented the use of organic fertilizer, compost, and biosolids to reduce nutrient runoff from agricultural sites while reducing the load on landfills by using organic waste [29-33]. Further, avoiding synthetic pesticides is imperative to reducing the tradeoff of chemical pesticide control. Finally, safe urban farming practices can be applied to the greening and revitalization of brownfields [33].

It should also be noted that the circularity of urban agriculture relates to resource recovery or waste reuse. Figure 3 shows the conceptual circularity of urban agriculture systems, including soil-based and soilless agriculture [34,35]. Water lies at the center of both soil-based and soilless agricultural systems, including aeroponic, hydroponic, and aquaponic. In this sustainable model, fresh resources are reused via resource recovery, including that of water and plant nutrients [36]. 


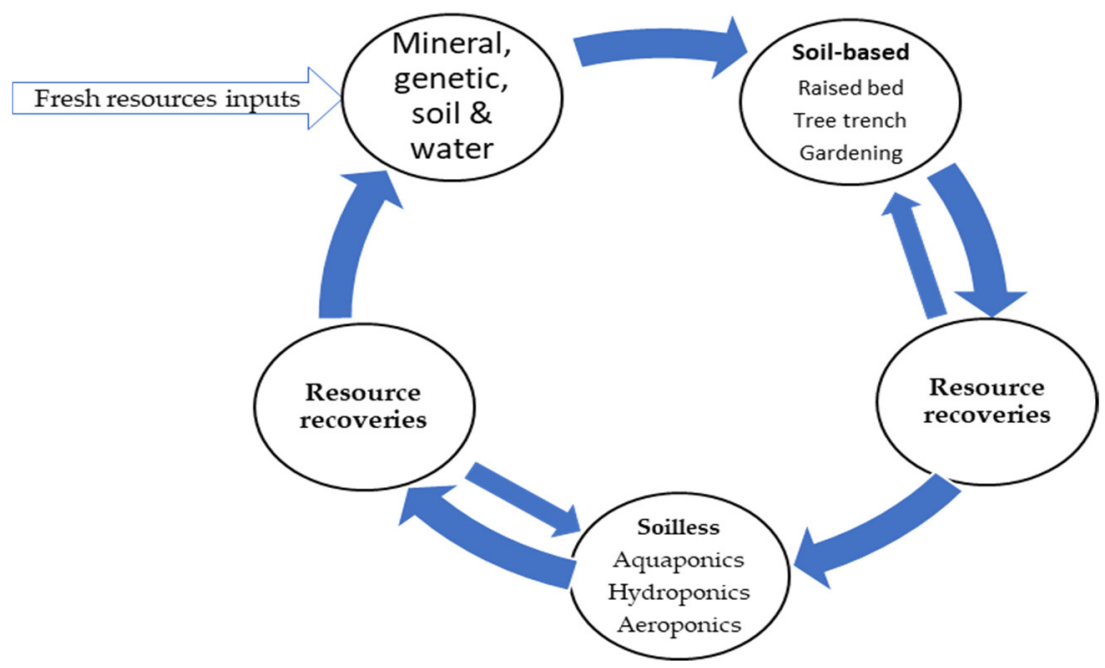

Figure 3. A Circular Urban Agriculture.

\subsection{Stormwater Management in a Circular Economy}

By 2050, two-thirds of the global population is expected to live in cities. This will significantly increase the consumption of natural resources and waste production, which may damage ecosystems [37]. Rapid urban development, in addition to the increase in impervious areas, can make cities vulnerable and prone to stormwater-related damages, including flooding and disruption of aquatic ecosystems [38]. This problem may exacerbate the challenge of conventional urban stormwater infrastructure, also known as gray infrastructure [39]. The gray approach is designed to move stormwater away as quickly as possible from urban areas via pipes and conduits with a limited capacity, which can be overwhelmed during the wet season, thus contaminating local waterways. This centralized stormwater infrastructure applies a "Take-Use-Dispose" strategy, which is similar to the "Take-Make-Dispose" strategy of the linear economy. Traditional gray stormwater management follows a linear economic model and does not provide as many benefits as green infrastructure. This externality of stormwater gray infrastructure can be addressed by stormwater green infrastructures, such as bioretention cells, green roofs, tree trenches, retention ponds, or pervious pavements.

In contrast to the gray infrastructure, stormwater green infrastructure is a distributed model that treats stormwater runoff close to the source. It enhances locally produced ecosystem benefits by reducing stormwater runoff, recharging groundwater, reducing flooding, and increasing stormwater water filtration and source water protection $[2,40]$. Despite these benefits, limited studies have addressed the role and challenges associated with expanding stormwater green infrastructure to support the mission of sustainable cities with a circular economy.

Several studies have recognized that water is central to the circular economy and that the circularity of water resource management is crucial for building sustainable cities [41]. Stormwater green infrastructure addresses all three principles of circular economy [42]: (1) designing waste externalities by optimizing consumptive use of stormwater for use in agricultural or evaporative cooling; (2) keeping resources in use by optimizing resource yields within water systems; and (3) regenerating natural capital by preserving and enhancing natural capital, such as river restoration, pollution prevention, reduction of energy use, and reduction of combined sewer overflows. Table 3 provides examples of stormwater green infrastructure that enhances water circularity. The result shows that stormwater GIs can address all three core principles of the circular economy. 
Table 3. Aligning stormwater green infrastructure activities with the principles of the circular economy.

\begin{tabular}{|c|c|c|c|}
\hline $\begin{array}{l}\text { Circular Economy } \\
\text { Principles [40] }\end{array}$ & Water Systems Management & $\begin{array}{l}\text { Examples of Stormwater Green } \\
\text { Infrastructure }\end{array}$ & References \\
\hline $\begin{array}{l}\text { Principle 1: } \\
\text { Design out waste } \\
\text { externalities }\end{array}$ & $\begin{array}{l}\text { Optimize consumptive use of water } \\
\text { within sub-basin in relation to adjacent } \\
\text { sub-basins (e.g., use in agriculture or } \\
\text { evaporative cooling) } \\
\text { Optimize the amount of energy, miner- } \\
\text { als, and chemicals use in the operation } \\
\text { of water systems in concert with other } \\
\text { systems. }\end{array}$ & $\begin{array}{l}\text { - Bioretention cell, rain gardens, } \\
\text { retention ponds, constructed } \\
\text { wetlands }\end{array}$ & [43-48] \\
\hline $\begin{array}{c}\text { Principle 2: } \\
\text { Keep Resources in Use }\end{array}$ & $\begin{array}{l}\text { Optimize resource yields (water use } \\
\text { and reuse, energy, minerals, and chem- } \\
\text { icals) within water systems. } \\
\text { Optimize energy or resource extrac- } \\
\text { tion from the water system and maxi- } \\
\text { mize their reuse. } \\
\text { Optimize value generated in the inter- } \\
\text { faces of the water system with other } \\
\text { systems. }\end{array}$ & $\begin{array}{l}\text { Using municipal biosolids for } \\
\text { the growing media of bio- } \\
\text { retention, urban gardening, } \\
\text { tree trenches, and landscaping. } \\
\text { Producing biogas and fertile or- } \\
\text { ganic fertilizer using an anaer- } \\
\text { obic digester }\end{array}$ & [30-32] \\
\hline $\begin{array}{c}\text { Principle 3: } \\
\text { Regenerate Natural } \\
\text { Capital }\end{array}$ & $\begin{array}{l}\text { Maximize environmental flows by } \\
\text { reducing consumptive and non- } \\
\text { consumptive uses of water. } \\
\text { Preserve and enhance the natural cap- } \\
\text { ital (e.g., river restoration, pollution } \\
\text { prevention, quality of effluent, etc.) } \\
\text { - Ensure minimum disruption to natu- } \\
\text { ral water systems from human interac- } \\
\text { tions and use. }\end{array}$ & $\begin{array}{l}\text { - } \quad \text { Managed groundwater recharge } \\
\text { tion ponds and fish hatcheries } \\
\text { when the outflow is returned } \\
\text { to the point of diversion, }\end{array}$ & [49-51] \\
\hline
\end{tabular}

Based on this review, a conceptual model of a circular water system is proposed. Figure 4 illustrates a conceptual model of an integrated circular water management (ICWM) system. The components of ICWM include source water and receiving water (rivers), water supply management (industrial, domestic, and agricultural uses), wastewater collection and treatment, and stormwater management and groundwater recharge. In the integrated system, each of the three main water resources categories is addressed, including potable water, stormwater, and wastewater collection and treatment. The wastewater collection and treatment systems include a municipal-separate-storm-sewer system (MS4), separate sewer system (SSS), combined sewer system (CSS), and wastewater treatment. The primary focus of the proposed ICWM is to reduce waste while maximizing reuse by linking all major components of urban water and wastewater systems within a single complex ecosystem. This proposed complex system provides the maximum benefit, including reduced sewer overflows, stormwater, or rainwater reuse, reduced demand for water supply, and grey and recycled water reuse. In the integrated approach, stormwater GIs plays an essential role in maintaining water circularity in the urban setting. This implies that stormwater GIs can serve as a tool for stormwater retention and treatment for runoff from UA and can also provide wastewater retention and treatment for combined sewer overflows (CSOs). The water treated by stormwater GIs can be reused for non-potable water uses, including irrigation, cooling, and groundwater recharge [52-54]. 


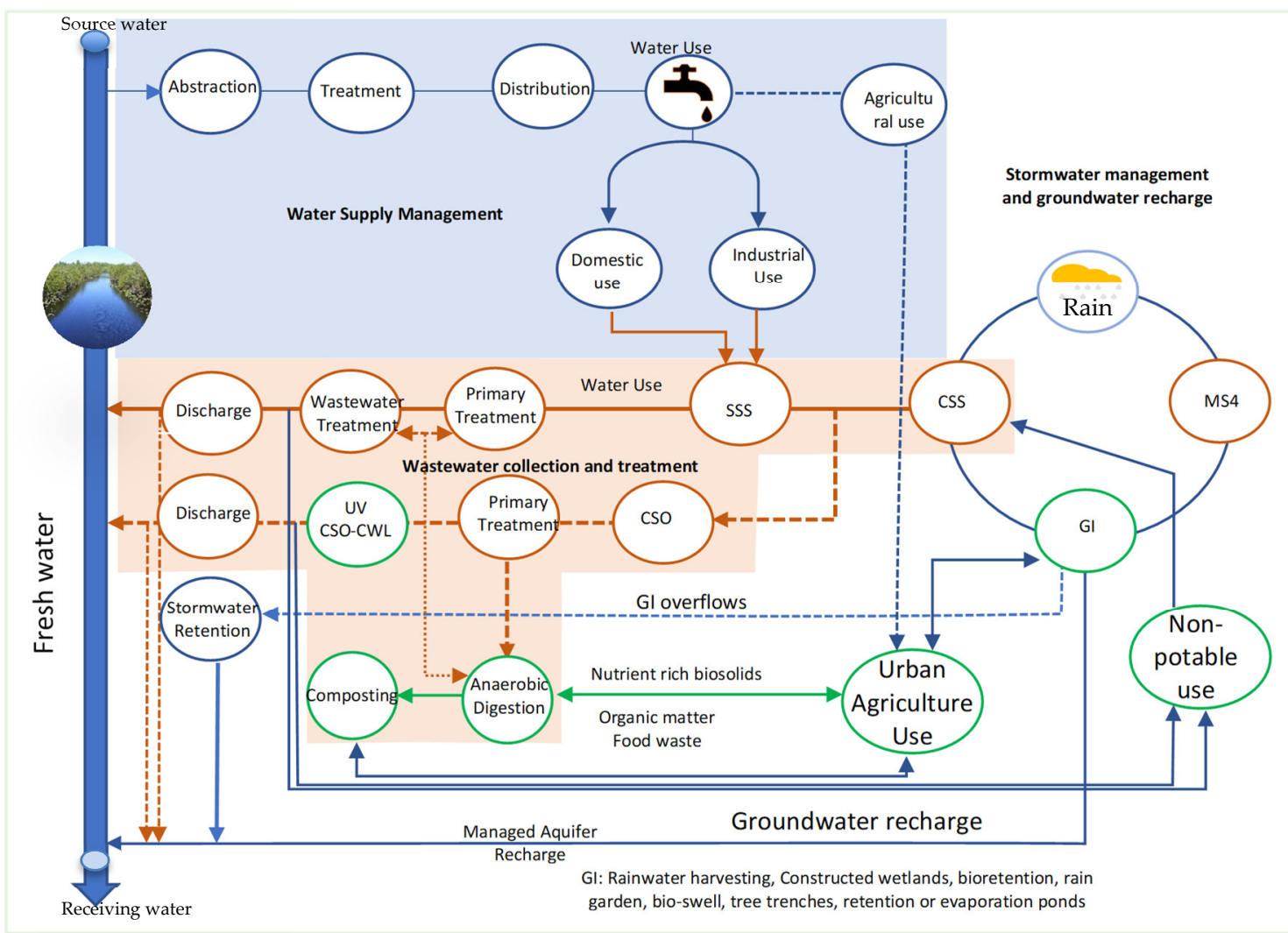

Figure 4. Conceptual framework for integrated urban water, wastewater, stormwater system management circularity: GIGreen infrastructure; CSO-CWL-Combined sewer overflow constructed wetlands, CSO-Combined sewer overflows, CSSCombined sewer system, SSS—Separate sewer system, MS4-Municipal separate storm sewer system, UV—Ultraviolet light wastewater treatment.

This implies that stormwater GIs can have a multifunctional role in a circular wastewater management approach and can have a significant role in addressing the impact of CSOs on the global aquatic ecosystem. Combined sewer overflows have been reported to be responsible for degrading urban aquatic ecosystems globally by discharging untreated raw sewage directly into the receiving waters. Combined sewer overflow constructed wetlands (CSO-CWLs) have been proposed to address this challenge. According to several researchers, CSO-CWLs can effectively purify CSOs [52-55]. According to Tonderaab [54], this type of stormwater GI can remove $85 \%$ of ammonia and carbonaceous Biochemical Oxygen Demand (BOD).

In addition, CSO-CWLs can remove $70 \%$ of micropollutants and pharmaceutical products [56]. According to Ruppelta et al. [57], this type of stormwater GIs can remove 80-91\% BOD, 60-85\% Chemical Oxygen Demand (COD), and 80-95\% Total Suspended Solids (TSS). Further, in areas where stormwater GIs is not possible, end-of-pipe systems can be applied, such as primary settling tanks, dynamic rotating belt filters, adsorption on granular activated carbon, and UV disinfection steps for further CSOs treatment [58].

Furthermore, anaerobic digestion is a key part of wastewater management circularity because it uses waste to generate renewable energy and biogas and to provide wastewater stabilization for land application. Nutrient-rich biosolids can be used for urban agriculture, including urban trees. Food waste and organic matter from urban agriculture can provide carbon sources for anaerobic digestion. In addition, anaerobic digestion can be applied to treat solid waste generated by primary and secondary wastewater treatment systems designed to purify wastewater received from CSOs and SSS.

Rainwater harvesting is also important in the integrated cycle of water management and provides benefits such as reducing CSOs to improve wastewater treatment, reducing 
the cost of damage caused by floods, decreasing water demand, reducing the cost of drinking water production, aquifer recharging, and improving stream base flows [26,59]. A recent study demonstrated that rainwater harvesting can provide up to $25 \%$ of the water that is used for washing and flushing, with no treatment, in India [45]. In Australia, rainwater harvesting can satisfy up to $100 \%$ of toilet flushing and laundry use [60] and $97 \%$ of drinking water demands [61]. In China, the integration of rainwater harvesting, and drip irrigation can increase apple fruit production by $54 \%$ [25]. In the State of Florida, rainwater harvesting can reduce flooding by $20 \%$ [26]. It must also be noted that if rainwater harvesting is used to reduce flooding and CSOs, the water captured from impervious areas, including roofs in cisterns, should be used for some appropriate purpose before the next significant rain event [62]. Overall, the literature study shows that rainwater harvesting is an important part of sustainable urban water resource management and urban farming in a circular economy.

\subsection{Stormwater Management in a Circular Economy}

Stormwater GIs can be designed to reduce runoff and flooding while providing local fresh foods. They are considered to be more adaptive strategies for both short- and longterm urban stormwater management planning than gray infrastructure [63]. Nevertheless, integration of stormwater management and urban agriculture (ISMUA) is not part of conventional urban land use planning. In addition, there is also limited field data related to appropriate methods for implementing ISMUA. There is a knowledge gap and a lack of policy regarding the successful implementation of the ISMUA system. This study focused on possible means of implementing ISMUA for the maximum ecosystem benefit of the integrated system while highlighting approaches to reduce tradeoffs.

Based on an extensive literature study, three means of implementing ISMUA were identified: (1) use of stormwater GIs as food-producing systems; (2) use of urban agriculture as urban stormwater GIs; and (3) non-consumptive and consumptive use of harvested stormwater for urban agriculture and stormwater GIs. Figure 5 illustrates ISMUA. Previous studies have examined applying stormwater GIs for food production, such as green roofs or rooftop gardening, which are commonly used to retain stormwater and can be used for rooftop gardening. Recent literature studies $[34,64,65]$ extensively discussed how stormwater GIs can address urban food insecurity and energy conservation while retaining stormwater during peak flows. This approach focuses on the water-energyfood-ecosystem security nexus approach to contribute to the sustainable and resilient development of cities. The environmental benefits of green roofs are well recognized as mitigating the effects of urban heat islands and stormwater runoff management. According to Berardi et al. [66], green roofs can reduce heat flow by up to $90 \%$ in summer and up to $30 \%$ in winter. In addition, green roofs can contribute to urban food production. For example, in Singapore, green roofs have produced about 35\% of the domestic food demand [65].

Nevertheless, the capacity of food-producing green roofs to mitigate stormwater quantity and quality must be verified using controlled field data. For example, adding compost to the growing media of GIs in the case of productive green roofs may have mixed effects on mitigating stormwater quality. Using growing media or soil mix with excessive plant nutrients and the application of mineral fertilizer could result in the potential leaching of nitrogen and phosphorus [67-70]. In contrast, the addition of compost was reported to be a potential absorbent or treatment method for heavy metals from industrial and landfill stormwater [71]. The substrate or growing media of green roofs is critical for the success of the system as a tool for stormwater quality and quantity management. In contrast to the most commonly used lightweight substrates for mitigating urban heat islands, and stormwater quantity and quality, sustainable food production on green roofs requires a greater quantity of organic matter and an optimum level of plant nutrients. This demonstrates the need to balance the effect of the green roof substrate by using stable compost materials. The addition of locally available recycled materials, such as biochar, perlite, and zeolites, are reported to reduce nutrient leaching [69,72]. 


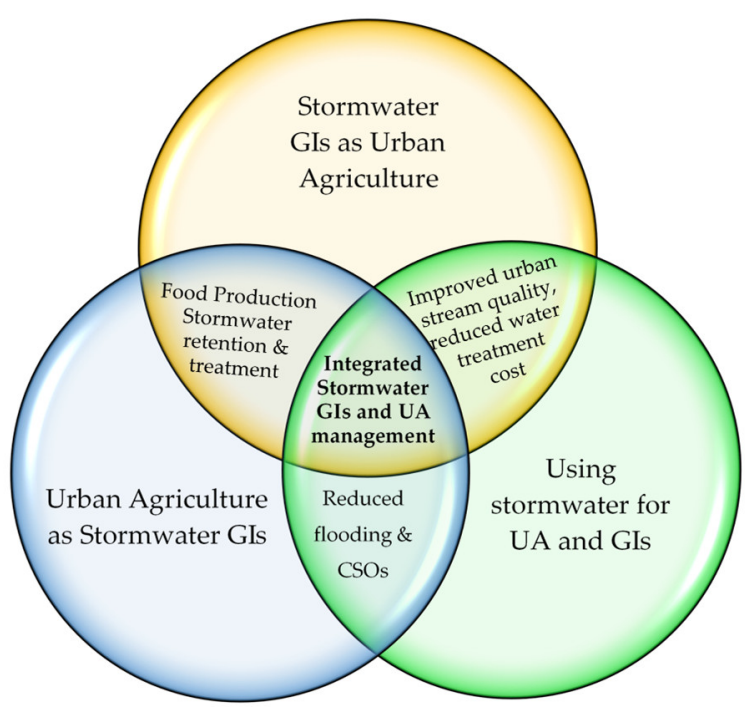

Figure 5. Integrated stormwater green infrastructure and urban agriculture (ISMA).

In addition, stormwater GIs can provide food production services while mitigating stormwater quality and quantity. Several studies have demonstrated that vegetable gardens can reduce stormwater runoff while providing good food yields [43,48]. This indicates that characterization of GIs is important prior to using them to treat stormwater because stormwater carries a range of contaminants including, total suspended solids (TSS), heavy metals, polycyclic aromatic hydrocarbons (PAHs), nitrogen, and phosphorous compounds.

Furthermore, the benefit of stormwater for urban agriculture can be described in two ways. First, urban agriculture can provide the benefit of stormwater retention by reducing runoff during peak flows [73]. Second, water harvesting in appropriate containers during rain or peak flows can be used to irrigate urban agriculture and for other consumptive uses.

Finally, other noticeable benefits of urban agriculture include purifying reclaimed wastewater and revitalization of brownfields [34,40]. Treating wastewater using a hydroponic system allows nutrient recovery and reuse while producing food [74,75]. Another study shows that wastewater supplemented with artificial lighting improved nitrogen removal [76].

\subsection{Enhancement of Ecosystem Services}

Ecosystem services are a crucial component of urban sustainability and resilience. They are the processes that directly or indirectly contribute to sustainable human wellbeing, and thus they are considered to be "natural capital" [77]. Table 4 illustrates examples of ecosystem services provided by integrated systems of UA and stormwater GIs. The quality and quantity of ecosystem services depend on biodiversity, which is a key component of the environmental benefits of urban agriculture. As indicated in Table 4 and Figure 4, integrated stormwater GIs and urban agriculture management help cities to overcome the existing barriers related to urban agriculture and focus on the synergies of the ecological benefits of the two sectors. Integration of stormwater management and urban agriculture reduces, if not eliminates, possible sectoral disservices. For example, urban agriculture may result in ecosystem disservices, including nutrient runoff and competition for water from other services [78]. Table 4 depicts possible enhancements of ecosystem services provided by integrating urban agriculture and stormwater management. This indicates, in addition to providing and regulating services, the integrated system can have a significant contribution to the creation of cultural, economic, and educational opportunities for a city. 
Table 4. Ecosystem services and examples of integrated stormwater management and urban agriculture.

\begin{tabular}{|c|c|c|c|}
\hline & Ecosystem Services & $\begin{array}{l}\text { Example of Integrated Stormwater } \\
\text { Management and Urban Agriculture }\end{array}$ & References \\
\hline \multirow{3}{*}{ Provision: } & Food supply & $\begin{array}{l}\text { Food-producing rain gardens and green } \\
\text { roofs, urban fruit trees, urban food forest }\end{array}$ & {$[4,9,23,79,80]$} \\
\hline & $\begin{array}{l}\text { Water supply (non-potable use for } \\
\text { consumptive uses: harvested or } \\
\text { reclaimed water) }\end{array}$ & $\begin{array}{l}\text { Graywater reuse through bioretention, } \\
\text { rainwater harvesting, using harvested } \\
\text { water for agriculture to reduce water } \\
\text { supply/demand. }\end{array}$ & {$[10,61,81]$} \\
\hline & Wood and fiber & Urban forest & [82] \\
\hline \multirow{7}{*}{ Regulating: } & Drinking water quality enhancement & Stormwater retention and filtration & {$[2,26,83]$} \\
\hline & Flood control & $\begin{array}{l}\text { Bioretention, rainwater harvesting, using } \\
\text { harvested water for agriculture }\end{array}$ & {$[2,26,83]$} \\
\hline & Wastewater purification & $\begin{array}{c}\text { Using hydroponic for food production and } \\
\text { wastewater treatment }\end{array}$ & [40] \\
\hline & $\begin{array}{l}\text { Stormwater quality enhancement (N, P, } \\
\text { coliform, total suspended solids) }\end{array}$ & Bioretention & {$[23,79]$} \\
\hline & Air purification/air quality regulation & Urban trees, urban forest & {$[2,84,85]$} \\
\hline & Carbon sequestration & Urban trees, urban forest & [84-87] \\
\hline & Temperature regulation & Urban trees, urban forest & [2] \\
\hline \multirow{3}{*}{ Cultural: } & Esthetic value & $\begin{array}{l}\text { Urban fruit trees, green roofs, Bioretention, } \\
\text { Tree trenches }\end{array}$ & {$[2,4]$} \\
\hline & Recreation & Bioretention, Tree trenches & {$[2]$} \\
\hline & Educational opportunities & Green roofs, Bioretention, Tree trenches & {$[2,4]$} \\
\hline
\end{tabular}

Nevertheless, the selection of an appropriate type of stormwater GIs is imperative to efficiently treat stormwater quality. Table 5 illustrates typical examples of bioretention cells with treatment efficiency for different water contaminants. Based on this example, the removal rate of total nitrogen (TN) and total phosphorous (TP) by the bioretention cell can range from $30 \%$ to $90 \%$, and $67 \%$ to $95 \%$, respectively. According to Jay et al. [88], bioretention cells can remove more than $80 \%$ of polycyclic aromatic hydrocarbons (PAHs). There is limited data available for the PAHs removal. Overall, one should note that the removal rate of bioretention depends on various factors including soil mix, design, depth of saturated zone [79-91].

Table 5. Summary of stormwater quality treatment efficiency (\%) of GIs based on the literature review.

\begin{tabular}{|c|c|c|c|c|c|c|}
\hline \multirow{2}{*}{ References } & TN & TP & TSS & PAHs & \multirow{2}{*}{ Type of Study and Country } & \multirow{2}{*}{ Addition of Enhancing Materials } \\
\hline & \multicolumn{4}{|c|}{ Removal Efficiency (\%) } & & \\
\hline [79] & 82 & 95 & 94 & & Laboratory; Artificial rainfall, USA & \\
\hline$[80]$ & 51 & 67 & 70 & & Field Study, USA & \\
\hline$[81]$ & 90 & & & & Field Study, USA & Wood chips \\
\hline$[82]$ & 86 & & & & Laboratory & \\
\hline [83] & 64 & 89 & & & Field Study, China & \\
\hline$[84]$ & 56 & & & & Field Study, USA & \\
\hline$[84]$ & 95 & 94 & & & Laboratory, China & Fe-biochar \\
\hline$[86]$ & 80 & 95 & 95 & & Field study, China & Zeolites \\
\hline$[87]$ & & 90 & 95 & & Laboratory, Sweden & \\
\hline$[89]$ & & & & 4 to $100 \%$ & & \\
\hline [91] & $29.8-123.0$ & & & & Laboratory & \\
\hline
\end{tabular}


Another typical example of integrated stormwater GIs and UA is rooftop farming, also known as a productive green roof. It is often referred to as the food-water-energy nexus $[62,63]$. This type of integrated system provides multiple ecosystem services, including stormwater management, food production, energy conservation, education, aesthetics, recreation, economic and social benefits. Brooklyn Grange of urban rooftop farm in the New York City [92], and the Farm at Mill Creek in the city of Mill Creek, Philadelphia [93] are among many such integrated rooftop farms in the USA. Furthermore, rooftop farming is popular in developing countries [94].

\section{Discussion}

\subsection{Enhancement of Ecosystem Services}

Our findings were compared with two other different perspectives pertaining to environmental management in urban areas. First, most authors focus on a separate land-use approach in addressing urban food insecurity and urban stormwater management, rather than cross-agency collaboration in planning and management. The separate approach describes various ways of addressing a single environmental or urban land issue rather than the holistic approach. For example, van der Wielab [28] and others [30-34] focused on sustainable practices, including nutrient recycling, and reusing biowastes to address food insecurity. Conversely, Nilson et al. [38] and others [39-42] emphasized the distributed approach of urban stormwater management, which does not necessarily include urban agriculture. In this review, both theoretical and technical concepts for the mechanism of integration of UA and GSI are elaborated (Figures 3 and 4).

The second comparison is related to integrated environmental management (IEM) and integrated water resource management. In this approach, there are a significant number of publications regarding general theories and practices that provide guiding principles to achieve the priority goals while minimizing the negative impacts of other activities on the individual elements of the environment. However, these do not specifically address current and future issues related to urban stormwater management and urban agriculture as an integrated approach. For example, Posivakova et al. [95] discuss the characterization of selected IEM approaches in a broader context, identifying the questions of "what" and "how", and examining theories that are key to planning and implementation of holistic environmental management tools. In the current literature regarding IEM approaches, linking urban agriculture and stormwater management theory and practices, in particular, is missing. For example, Biswas et al. [96] and other similar studies [95,97] emphasized water resource and ecosystem management, and they did not specifically address competing land-use practices of urban agriculture and other urban practices.

Furthermore, several literature reviews demonstrate the significance of ecosystem services in urban resilience, and some even propose that ecosystem services should be included in urban planning processes [15-18,21,22,98]. Nevertheless, there are limited studies that provide detailed perspectives regarding the strategic integration of UA and stormwater GIs economic sectors. To enhance the ecosystem services of these two economic sectors, strategic integration of both ecosystem benefits is critical. Many studies recognize the importance of careful consideration of ecosystem services in urban planning, but they are limited in the details provided for how to expand UA to address urban food insecurity without affecting urban water resources. In our findings, a limited number of studies show that sustainable urban agriculture can be designed to both provide provisional ecosystem services, such as food supply, and regulate water supply and urban stream water quality [23-26].

Similarly, we also evaluated the circular economy literature studies. These studies are also very broad and do not specifically provide an alternative to address issues related to urban agriculture [43-51,98,99]. For example, Sreeharsha et al. [98] focuses on the energy, water, and resource recovery in a broader context but does not specifically address the role of urban agriculture to address urban food insecurity and nutrient recycling. Nevertheless, the circularity of urban agriculture and stormwater management requires 
resource recovery or waste reuse. In both soil-based and soilless urban agriculture, water is an integral component of the circularity of urban agriculture. As indicated in Figure 2, which shows the circular urban agriculture model, freshwater resources, including water, plants, and nutrients, are reused. It must be noted that the construction of resilient cities requires the integration of sustainable practices, including sustainable urban agriculture and urban stormwater management. Separating urban agriculture from other land uses cannot address key urban issues related to food insecurity and land scarcity.

This study shows that providing an in-depth analysis of the ecosystem service-based integration of UA and GSI is crucial for the fast-growing and urbanizing world. A considerable number of studies have recommended the integration of ecosystem services into urban planning from general perspectives but do not specifically provide guidelines for linking or integrating the multiple functions of ecosystem services of different land uses. For example, Marino et al. [93] and others [92,100] focus on the importance of the integration of ecosystem services and green infrastructure at multiple scales in a broader context. This paper also emphasizes ecosystem services but addresses the "what" and "how" questions relating to the theories and practices for city planners or regulators. This analysis provides insights pertaining to ecosystem-based adaptation and has the potential to help cities meet various environmental, social, and economic objectives, including resilience to climate change [92-94,100,101]. In addition, this paper specifically discussed the possible means of linking ecosystem services of the two economic sectors, i.e., UA and stormwater GIs.

Finally, in the integrated system, the selection of appropriate stormwater GIs is vital. As illustrated in Table 5, a wide range of variability was noted in the removal rate of water contaminants in bioretention cells. This variation is attributed to the difference in the design, soil mix, and nutrient management practices. Overall, further studies are necessary for key stormwater GIs, including bioretention cells, and extensive and intensive green roofs.

\subsection{Limitation of the Study}

The findings of this study should be considered in light of its limitations. The limitations of this study depend on the parameters set for the literature review, which are arbitrary and could limit the inclusion of other articles that may be of interest to the aims of the research. Other forms of publication, such as conference reviews and book chapters, were excluded. The research methodology consciously limited the selection of articles in an attempt to focus on the quality of the content with explicit reference to urban agriculture and green stormwater infrastructure, rather than the number of articles investigated.

A possible improvement could be made by integrating a new combination of keywords as parameters for the literature review, and the collection of additional water quality and quantity data that represent a longer time period. This could include the integration of environmental planning and urban agriculture to verify approaches for the integration of sustainable urban agriculture with other environmental management practices. Similarly, urban planning for agriculture, adaptive environmental management, and urban farming, or urban agriculture and urban resilience, may provide additional perspectives on how to integrate urban agriculture with other environmental management practices for future resilient cities.

\section{Conclusions}

Based on this study, it can be concluded that there are various approaches to integrating the ecosystem services of urban agriculture and stormwater green infrastructures for the construction of resilient cities with a circular economy. Overall, the results show that integrating urban agriculture with stormwater bioretention can enhance urban food production while protecting urban water quality. Urban agriculture can be designed not only to address urban food insecurity but also to manage stormwater runoff and prevent combined sewer overflows. Increased optimization of design and materials to remove total nitrogen and total phosphorous, in addition to a collection of adequate performance 
data of bioretention during different rain events and agricultural activities, can provide additional insights for such integration. Finally, the findings of this study are useful for researchers, urban planners, and environmental managers. These findings improve our understanding of the mechanisms used to integrate the ecosystem services of urban agriculture and stormwater green infrastructure management to enhance the resilience of future cities, thereby addressing growing concerns regarding urban food insecurity and urban stormwater-related issues. Therefore, the proposed sustainability practices and ways of integrating urban agriculture and stormwater green infrastructure would benefit societies at local and global levels in the exploration of mechanisms for adaptation to extreme events related to climate change.

Author Contributions: In this study, the conceptualization, data analysis, and draft preparation were carried out by T.D. Significant contributions were received from K.Z., H.A. and H.T. in the areas of review and editing. All authors have read and agreed to the published version of the manuscript.

Funding: This research was funded by U.S. Geological Survey through DC Water Resources Research Institute under section 104(b): IPETT Project Number: 2020DC169B. https:/ / www.udc.edu/ causes/land-grant/wrri/. Accessed on 30 April 2021.

Institutional Review Board Statement: Not applicable.

Informed Consent Statement: Not applicable.

Data Availability Statement: All the data are stored on the University of the District of Columbia's secured network and available up on request.

Acknowledgments: DC Water Resources Research Institute for the financial support of the study.

Conflicts of Interest: The authors declare no conflict of interest.

\section{References}

1. Botkin, D.B.; Keller, E.A. Environmental Science: Earth as a Living Planet, 9th ed.; Wiley \& Sons: New York, NY, USA, 2014.

2. Thiagarajan, M.; Newman, G.; Zandt, V.S. The Projected Impact of a Neighborhood-scaled Green Infrastructure Retrofit. Sustainability 2018, 10, 3665. [CrossRef]

3. Masi, F.; Rizzo, A.; Bresciani, R.; Conte, G. Constructed wetlands for combined sewer overflow treatment: Ecosystem services at Gorla Maggiore, Italy. Ecol. Eng. 2017, 98, 427-438. [CrossRef]

4. Safayet, M.; Arefin, M.F.; Hasan, M.M.U. Present practice, and future prospect of rooftop farming in Dhaka city: A step towards urban sustainability. J. Urban Manag. 2017, 6, 56-65. [CrossRef]

5. Caputo, S.; Schoel, V.; Specht, K.; Grard, B.; Blythe, C.; Cohen, N.; Fox-Kamper, R.; Hawes, J.; Newell, J.; Ponizy, L. Applying the food-energy-water nexus approach to urban agriculture: From FEW to FEWP (Food-Energy-Water-People). Urban For. Urban Green. 2021, 58, 126934. [CrossRef]

6. Tappert, S.; Klöti, T.; Drilling, M. Contested urban green spaces in the compact city: The (re-)negotiation of urban gardening in Swiss cities. Landsc. Urban Plan. 2018, 170, 69-78. [CrossRef]

7. Haysom, G.; Battersby, J.; Park-Ross, R. Food Sensitive Planning and Urban Design-A Blueprint for a Future South African City? In Working Paper Series; Devereux, S., Makwela, M., Eds.; DSI-NRF Centre of Excellence in Food Security: Cape Town, South Africa, 2020; Volume 007, pp. 1-101.

8. He, G.; Geng, C.; Zhai, J.; Zhao, Y.; Wang, Q.; Jiang, S.; Zhu, Y.; Wang, L. Impact of food consumption patterns change on agricultural water requirements: An urban-rural comparison in China. Agric. Water Manag. 2021, 243, 106504. [CrossRef]

9. Amos, C.C.; Rahman, A.; Karim, F.; Gathenya, J.M. A scoping review of roof harvested rainwater usage in urban agriculture: Australia and Kenya in focus. J. Clean. Prod. 2018, 202, 174-190. [CrossRef]

10. Chowdhury, R.K. Greywater reuse through a bioretention system prototype in the arid region. Water Sci. Technol. 2015, 72, 2201-2211. [CrossRef]

11. Prudencio, L.; Null, S.E. Stormwater management and ecosystem services: A review. Environ. Res. Lett. 2018, 13, 1-13. [CrossRef]

12. Ronchi, S. Ecosystem Services for Planning: A Generic Recommendation or a Real Framework? Insights from a Literature Review. Sustainability 2021, 13, 6595. [CrossRef]

13. Meerow, S.; Newell, J.P.; Stults, M. Defining urban resilience: A review. Landsc. Urban Plan. 2016, 147, 38-49. [CrossRef]

14. Bai, Y.; Guo, R. The construction of green infrastructure network in the perspectives of ecosystem services and ecological sensitivity: The case of Harbin, China. Glob. Ecol. Conserv. 2021, 27, e01534. [CrossRef]

15. Onandi, G.; Schittko, C.; Ryo, M.; Bernard-Verdier, M.; Heger, T.; Joshi, J.; Kowarik, I.; Gessler, A. Ecosystem functioning in urban grasslands: The role of biodiversity, plant invasions and urbanization. PLoS ONE 2019, 14, e0225438. [CrossRef] 
16. DEWHA (Department of the Environment Water, Heritage and the Arts). Ecosystem Services: Key Concepts and Applications; Occasional Paper Series No. 1, 2009; National Library of Australia Cataloguing-in-Publication Entry: Canberra, Australia, 2009; pp. 1-26.

17. Hansen, R.; Pauleit, S. From Multifunctionality to Multiple Ecosystem Services? A Conceptual Framework for Multifunctionality in Green Infrastructure Planning for Urban Areas. AMBIO 2014, 43, 516-529. [CrossRef]

18. McPhearson, T.; Hamstead, Z.A.; Kremer, P. Urban Ecosystem Services for Resilience Planning and Management in New York City. AMBIO 2014, 43, 502-515. [CrossRef]

19. Nyelele, C.; Kroll, C.N. The equity of urban forest ecosystem services and benefits in the Bronx, NY. Urban For. Urban Green. 2020, 53, 126723. [CrossRef]

20. Kim, I.; Kwon, H. Assessing the Impacts of Urban Land Use Changes on Regional Ecosystem Services According to Urban Green Space Policies Via the Patch-Based Cellular Automata Model. Environ. Manag. 2021, 67, 192-204. [CrossRef] [PubMed]

21. Yli-Pelkonen, V.; Niemela, J. Linking ecological and social systems in cities: Urban planning in Finland as a case. Biodivers. Conserv. 2005, 14, 1947-1967. [CrossRef]

22. Sebastiani, A.; Marando, F.; Manes, F. PM10 removal and urban heat island effect mitigation in the municipality of Rome (Italy). Urban For. Urban Green. 2021, 57, 126938. [CrossRef]

23. Shetty, N.H.; Hu, R.; Mailloux, B.J.; Hsueh, D.Y.; McGillis, W.R.; Wang, M.; Chandran, K.; Culligan, P. Studying the effect of bioswales on nutrient pollution in urban combined sewer systems. Sci. Total Environ. 2019, 665, 944-958. [CrossRef] [PubMed]

24. Mason, B.; Salís, M.R.; Parada, F.; Gabarrell, X.; Gruden, C. Intelligent urban irrigation systems: Saving water and maintaining crop yields. Agric. Water Manag. 2019, 226, 105812. [CrossRef]

25. Zhang, W.; Sheng, J.; Li, Z.; Weindorf, D.C.; Hu, G.; Xuan, J.; Zhao, H. Integrating rainwater harvesting and drip irrigation for water use efficiency improvements in apple orchards of northwest China. Sci. Hortic. 2021, 275, 109728. [CrossRef]

26. Deitch, M.J.; Feirer, S.T. Cumulative impacts of residential rainwater harvesting on stormwater discharge through a peri-urban drainage network. J. Environ. Manag. 2019, 243, 127-136. [CrossRef]

27. Cohen, N.; Wijsman, K. Urban agriculture as green infrastructure: The case of New York City. Urban Agric. Mag. 2014, $27,16-19$.

28. Lin, B.B.; Philpott, S.M.; Jha, S.; Liere, H. Urban Agriculture as a Productive Green Infrastructure for Environmental and Social Well-Being. In Greening Cities: Forms and Function (Advances in 21st Century Human Settlements); Tan, P.Y., Jim, C.Y., Eds.; Springer Nature: Singapore, 2017; pp. 155-179.

29. van der Wielab, B.Z.; Weijma, J.; van Middelaar, C.E.; Kleinked, M.; Buisman, C.J.N.; Wichern, F. Restoring nutrient circularity: A review of nutrient stock and flow analyses of local agro-food-waste systems. Resour. Conserv. Recycl. 2019, 3, 100014. [CrossRef]

30. Brown, S.; Ippolito, J.A.; Hundal, L.S.; Basta, N.T. Municipal biosolids-A resource for sustainable communities. Curr. Opin. Environ. Sci. Health 2020, 14, 56-62. [CrossRef]

31. Belyaeva, O.N.; Haynes, R.J.; Sturm, E.C. Chemical, physical and microbial properties, and microbial diversity in manufactured soils produced from+ co-composting green waste and biosolids. Waste Manag. 2012, 32, 2248-2257. [CrossRef]

32. Rigby, H.; Clarke, B.O.; Porter, N.A. A critical review of nitrogen mineralization in biosolids-amended soil, the associated fertilizer value for crop production and potential for emissions to the environment. Sci. Total Environ. 2016, 541, 1310-1338. [CrossRef] [PubMed]

33. Alcantara, H.J.P.; Doronila, A.I.; Nicolas, M.; Ebbs, S.D.; Kolev, S.D. Growth of selected plant species in biosolids-amended mine tailings. Miner. Eng. 2015, 80, 25-32. [CrossRef]

34. Appolloni, E.; Orsini, F.; Specht, K.; Thomaier, S.; Sanye-Mengual, E.; Pennisia, G.; Gianquinto, G. The global rise of urban rooftop agriculture: A review of worldwide cases. J. Clean. Prod. 2021, 296, 126556. [CrossRef]

35. Wang, M.; Dong, C.; Gao, W. Evaluation of the growth, photosynthetic characteristics, antioxidant capacity, biomass yield and quality of tomato using aeroponics, hydroponics and porous tube-vermiculite systems in bio-regenerative life support systems. Life Sci. Space Res. 2019, 22, 68-75. [CrossRef]

36. Environmental Protection Agency (USA). Brownfields and Urban Agriculture: Interim Guidelines for Safe Gardening Practices; EPA: Chicago, IL, USA, 2011.

37. Manríquez-Altamiranoa, A.; Sierra-Pérez, J.; Muñoza, P.; Gabarrell, X. Analysis of urban agriculture solid waste in the frame of circular economy: Case study of tomato crop in integrated rooftop greenhouse. Sci. Total Environ. 2020, 734, 139375. [CrossRef]

38. Veeck, G.; Veeck, A.; Yu, H. Challenges of agriculture and food systems issues in China and the United States. Geogr. Sustain. 2020, 1, 109-117. [CrossRef]

39. Nilsson, C.; Reidy, C.A.; Dynesius, M.; Revenga, C. Fragmentation and regulation of the world's large river systems. Science 2005, 308, 405-408. [CrossRef]

40. Dhakal, K.P.; Chevalier, L.R. Urban Stormwater Governance: The Need for a Paradigm Shift. Environ. Manag. 2016, 57, 1112-1124. [CrossRef]

41. Magwaza, S.T.; Magwaza, L.S.; Odindo, A.O.; Mditshwa, A. Hydroponic technology as decentralized system for domestic wastewater treatment and vegetable production in urban agriculture: A review. Sci. Total Environ. 2020, 698, 134154. [CrossRef]

42. Nika, C.E.; Vasilaki, V.; Expósito, A.; Katsou, E. Water Cycle and Circular Economy: Developing a Circularity Assessment Framework for Complex Water Systems. Water Res. 2020, 187, 116423. [CrossRef]

43. Tahir, S.; Steichen, T. Water and Circular Economy: A White Paper; Ellen MacArthur Foundation: Cowes, UK, 2018 ; pp. 1-35. 
44. Ng, K.T.; Herrero, P.; Hatt, B.; Farrelly, M.; McCarthy, D. Biofilters for urban agriculture: Metal uptake of vegetables irrigated with stormwater. Ecol. Eng. 2018, 122, 177-186. [CrossRef]

45. LeFevre, G.H.; Paus, K.H.; Natarajan, P.; Gulliver, J.S.; Novak, P.J.; Hozalski, R.M. Review of dissolved pollutants in urban stormwater and their removal and fate in bioretention cell. J. Environ. Eng. 2015, 141, 04014050. [CrossRef]

46. Hunt, W.F.; Davis, A.P.; Traver, R.G. Meeting Hydrologic and Water Quality Goals through Targeted Bioretention Design. J. Environ. Eng. 2012, 138, 698-707. [CrossRef]

47. Cao, C.; Zhang, P.; Ma, Z.P.; Ma, Z.B.; Wang, J.J.; Tang, Y.Y.; Chen, H. Coupling sprinkler freshwater irrigation with vegetable species selection as a sustainable approach for agricultural production in farmlands with a history of 50-year wastewater irrigation. J. Hazard. Mater. 2021, 414, 125576. [CrossRef]

48. Richards, S.; Rao, L.; Connelly, S.; Raj, A.; Raveendran, L.; Shirin, S.; Jamwal, P.; Helliwell, R. Sustainable water resources through harvesting rainwater and the effectiveness of a low-cost water treatment. J. Environ. Manag. 2021, 286, 112223. [CrossRef] [PubMed]

49. Richards, P.J.; Williams, N.S.G.; Fletcher, T.D.; Farrell, C. Can raingardens produce food and retain stormwater? Effects of substrates and stormwater application method on plant water use, stormwater retention and yield. Ecol. Eng. 2017, 100, 165-174. [CrossRef]

50. Mautner, M.R.L.; Foglia, L.; Herrera, G.S.; Galán, R.; Herman, J.D. Urban growth, and groundwater sustainability: Evaluating spatially distributed recharge alternatives in the Mexico City Metropolitan Area. J. Hydrol. 2020, 586, 124909. [CrossRef]

51. Meriano, M.; Howard, K.W.F.; Eyles, N. The role of midsummer urban aquifer recharge in stormflow generation using isotopic and chemical hydrograph separation techniques. J. Hydrol. 2011, 396, 82-93. [CrossRef]

52. Qi, J.; Brantley, S.T.; Golladay, S.W. Simulated irrigation reduction improves low flow in streams-A case study in the Lower Flint River Basin. J. Hydrol. Reg. Stud. 2020, 28, 100665. [CrossRef]

53. Rizzo, A.; Tondera, K.; Pálfy, T.G.; Dittmer, U.; Meyer, D.; Schreiber, C.; Zacharias, N.; Ruppelt, J.P.; Esser, D.; Molle, P.; et al. Constructed wetlands for combined sewer overflow treatment: A state-of-the-art review. Sci. Total Environ. 2020, 727, 138618. [CrossRef]

54. Tonderaab, K. Evaluating the performance of constructed wetlands for the treatment of combined sewer overflows. Ecol. Eng. 2019, 137, 53-59. [CrossRef]

55. Masi, F.; Rizzo, A.; Regelsberger, M. The role of constructed wetlands in a new circular economy, resource oriented, and ecosystem services paradigm. J. Environ. Manag. 2018, 216, 275-284. [CrossRef] [PubMed]

56. Brunsch, A.F.; Florez, P.Z.; Langenhoff, A.A.M.; Laak, T.L.T.; Rijnaarts, H.H.M. Retention soil filters for the treatment of sewage treatment plant effluent and combined sewer overflow. Sci. Total Environ. 2020, 699, 134426. [CrossRef]

57. Ruppelta, J.P.; Pinnekamp, J.; Tonderab, K. Elimination of micropollutants in four test-scale constructed wetlands treating combined sewer overflow: Influence of filtration layer height and feeding regime. Water Res. 2020, 169, 115214. [CrossRef]

58. Parde, D.; Patwa, A.; Shukla, A.; Vijay, R.; Killedar, D.J.; Kumar, R. A review of constructed wetland on type, treatment and technology of wastewater. Environ. Technol. Innov. 2021, 21, 101261. [CrossRef]

59. Botturi, A.; Daneshgar, S.; Cordioli, A.; Foglia, A.; Eusebi, A.L.; Fatone, F. An innovative compact system for advanced treatment of combined sewer overflows (CSOs) discharged into large lakes: Pilot-scale validation. J. Environ. Manag. 2020, $256,109937$. [CrossRef] [PubMed]

60. Nachshon, U.; Netzer, L.; Livshitz, Y. Land cover properties and rainwater harvesting in urban environment. Sustain. Cities Soc. 2016, 27, 398-406. [CrossRef]

61. Khan, Z.; Alim, M.A.; Rahman, M.M.; Rahman, A. A continental scale evaluation of rainwater harvesting in Australia. Resour. Conserv. Recycl. 2021, 167, 105378. [CrossRef]

62. Alim, M.A.; Rahman, A.; Tao, Z.; Samali, B.; Khan, M.M.; Shirin, S. Feasibility analysis of a small-scale rainwater harvesting system for drinking water production at Werrington, New South Wales, Australia. J. Clean. Prod. 2020, 270, 122437. [CrossRef]

63. Yamashita, S.; Watanabe, R.; Shimatani, Y. Smart Adaptation to Flooding in Urban Areas. Procedia Eng. 2015, 118, 1096-1103. [CrossRef]

64. Sadr, S.M.K.; Campos, A.C.; Fu, G.; Farmani, R.; Ward, S.; Butler, D. Strategic planning of the integrated urban wastewater system using adaptation pathways. Water Res. 2020, 182, 116013. [CrossRef]

65. Cristiano, E.; Deidda, R.; Viola, F. The role of green roofs in urban Water-Energy-Food-Ecosystem nexus: A review. Sci. Total Environ. 2021, 756, 143876. [CrossRef]

66. Berardi, U.; Hoseini, A.H.G.; Hoseini, A.G. State-of-the-art analysis of the environmental benefits of green roofs. Appl. Energy 2014, 115, 411-428. [CrossRef]

67. He, Q.; Lin, Z.; Dong, P.; Tang, W. Decontamination performance of a bioretention system using a simple sand-based filler proportioning method. Environ. Technol. 2020, 1-9. [CrossRef]

68. Yinghui, A.L.; Kishnani, N.T. Building Integrated Agriculture: Utilizing Rooftops for Sustainable Food Crop Cultivation in Singapore. J. Green Build. 2010, 5, 105-113.

69. Malcolm, E.G.; Reese, M.L.; Schaus, M.H.; Ozmon, I.M.; Tran, L.M. Measurements of nutrients and mercury in green roof and gravel roof runoff. Ecol. Eng. 2014, 73, 705-712. [CrossRef]

70. Eksi, M.; Rowe, D.B.; Cañero, R.F.; Cregg, B.M. Effect of substrate compost percentage on green roof vegetable production. Urban For. Urban Green. 2015, 14, 315-322. [CrossRef] 
71. Mullane, J.M.; Flury, M.; Iqbal, H.; Freeze, P.M.; Hinman, C.; Cogger, C.G.; Shi, Z. Intermittent rainstorms cause pulses of nitrogen, phosphorus, and copper in leachate from compost in bioretention systems. Sci. Total Environ. 2015, 537, 294-303. [CrossRef]

72. Pennanen, T.; Srivastava, V.; Sillanpää, M.; Sainio, T. Compost: Potent bio-sorbent for the removal of heavy metals from industrial and landfill stormwater. J. Clean. Prod. 2020, 273, 122736. [CrossRef]

73. Lonardo, S.D.; Baronti, S.; Vaccari, F.P.; Albanese, L.; Battista, P.; Miglietta, F.; Bacci, L. Biochar-based nursery substrates: The effect of peat substitution on reduced salinity. Urban For. Urban Green. 2017, 23, 27-34. [CrossRef]

74. Lohrberg, L.; Lička, L.; Scazzosi, L.; Timpe, A. Urban Agriculture Goes Green Infrastructure. In Urban Agriculture Europe, 1st ed.; JOVIS Verlag GmbH: Berlin, Germany, 2015; Chapter 4.2, pp. 126-138.

75. Gao, G.; Xiong, H.; Chen, J.; Chen, K.; Chen, P.; Yu, C.; Zhu, A. Hydroponic method for ramie and removal of nitrogen and phosphorus from livestock wastewater. Int. J. Phytoremediation 2018, 20, 545-551. [CrossRef]

76. Aleksandra, B. Efficiency of Nitrogen and Phosphorus Compounds Removal in Hydroponic Wastewater Treatment Plant. Environ. Technol. 2018, 40, 2062-2072.

77. Bawiec, A.; Pawęska, K.; Pulikowski, K. LED light use for the improvement of wastewater treatment in the hydroponic system. Environ. Technol. 2020, 41, 2024-2036. [CrossRef]

78. Costanza, R. Valuing natural capital and ecosystem services toward the goals of efficiency, fairness, and sustainability. Ecosyst. Serv. 2020, 43, 101096. [CrossRef]

79. Zhang, W.; Ricketts, T.H.; Kremen, C.; Carney, K.; Swinton, S.M. Ecosystem services and dis-services to agriculture. Ecol. Econ. 2007, 64, 253-260. [CrossRef]

80. Richards, P.J.; Farrell, C.; Tom, M.; Williams, N.S.G.; Fletcher, T.D. Vegetable raingardens can produce food and reduce stormwater runoff. Urban For. Urban Green. 2015, 14, 646-654. [CrossRef]

81. Nytofte, J.L.S.; Henriksen, C.B. Sustainable food production in a temperate climate-A case study analysis of the nutritional yield in a peri-urban food forest. Urban For. Urban Green. 2019, 45, 126326. [CrossRef]

82. Zalacáin, D.; Pérez, S.M.; Bienes, R.; Díaz, A.G.; Merlín, A.S. Turfgrass biomass production and nutrient balance of an urban park irrigated with reclaimed water. Chemosphere 2019, 237, 124481. [CrossRef]

83. Lee, J.; Gil, K. Evaluating bioretention hydrology and nutrient removal for restoring wetland function at artificial rainfall. Ecol. Eng. 2020, 150, 105823. [CrossRef]

84. Wang, R.; Zhang, X.; Li, M.H. Predicting bioretention pollutant removal efficiency with design features: A data-driven approach. J. Environ. Manag. 2019, 242, 403-414. [CrossRef]

85. Lopez-Ponnada, E.V.; Lynn, T.J.; Ergas, S.J.; Mihelcic, J.R. Long-term field performance of a conventional and modified bioretention system for removing dissolved nitrogen species in stormwater runoff. Water Res. 2020, 170, 115336. [CrossRef] [PubMed]

86. Luo, Y.; Yue, X.; Duan, Y.; Zhou, A.; Gao, Y.; Zhang, X. A bilayer media bioretention system for enhanced nitrogen removal from road runoff. Sci. Total Environ. 2020, 705, 135893. [CrossRef]

87. You, Z.; Li, Z.; Pan, S.; Shu, Z.; Pen, Y.P.; Chiang, P.; Peie, S.; Zhang, S. Performance evaluation of modified bioretention systems with alkaline solid wastes for enhanced nutrient removal from stormwater runoff. Water Res. 2019, 161, 61-73. [CrossRef] [PubMed]

88. Jay, J.G.; Plog, T.M.; Brown, S.L.; Grothkopp, F. Nutrient, Metal, and Organics Removal from Stormwater Using a Range of Bioretention Soil Mixtures. J. Environ. Qual. 2019, 48, 493-501. [CrossRef] [PubMed]

89. Chen, X.; Peltier, E.; Sturm, B.S.M.; Young, C.B. Nitrogen removal and nitrifying and denitrifying bacteria quantification in a stormwater bioretention system. Water Res. 2013, 47, 1691-1700. [CrossRef]

90. Xiong, J.; Ren, S.; He, Y.; Wang, X.C.; Bai, X.; Wang, J.; Dzakpasu, M. Bioretention cell incorporating Fe-biochar and saturated zones for enhanced stormwater runoff treatment. Chemosphere 2019, 237, 124424. [CrossRef] [PubMed]

91. Blecken, G.T.; Zinger, Y.; Deletić, A.; Fletcher, T.D.; Hedström, A.; Viklander, M. Laboratory study on stormwater biofiltration: Nutrient and sediment removal in cold temperatures. J. Hydrol. 2010, 394, 507-514. [CrossRef]

92. Cousiño, A.; Penha-Lopes, G. Ecosystem Based Adaptation: Concept and Terminology in Strategic Adaptation Planning (Municipal and Inter-Municipal) in Portugal. Sustainability 2021, 13, 6145. [CrossRef]

93. Di Marino, M.; Tiitu, M.; Lapintie, K.; Viinikk, A.; Kopperoinen, L. Integrating green infrastructure and ecosystem services in land use planning. Results from two Finnish case studies. Land Use Policy 2019, 82, 643-656. [CrossRef]

94. Harada, Y.; Whitlow, T.H.M.; Walter, T.; Bassuk, N.L.; Russell-Anelli, J.; Schindelbeck, R.R. Hydrology of the Brooklyn Grange, an urban rooftop farm. Urban Ecosyst. 2018, 21, 673-689. [CrossRef]

95. Pošiváková, T.; Hromada, R.; Pošivák, J.; Molnár, L.; Harvanová, J. Selected aspects of integrated environmental management. Ann. Agric. Environ. Med. 2018, 25, 403-408. [CrossRef]

96. Biswas, A.K. Integrated Water Resources Management: Is It Working? Water Resour. Dev. 2008, 24, 5-22. [CrossRef]

97. Naumann, S.; Anzaldua, G.; Berry, P.; Burch, S.; Davis, M.; Frelih-Larsen, A.; Gerdes, H.; Sanders, M. Assessment of the Potential of Ecosystem-Based Approaches to Climate Change Adaptation and Mitigation in Europe; Final Report to the European Commission, DG Environment. Contract No. 070307/2010/580412/ SER/B2; Ecologic Institute and Environmental Change Institute, Oxford University Centre for the Environment: Oxford, UK, 2011; p. 128.

98. Sreeharsha, R.V.; Mohan, S.V. Symbiotic Integration of Bioprocesses to Design a Self-Sustainable Life Supporting Ecosystem in a Circular Economy Framework. Bioresour. Technol. 2021, 326, 124712. [CrossRef] 
99. Wang, S.; Lin, X.; Yu, H.; Wang, Z.; Xia, H.; An, G.; Fan, G. Nitrogen removal from urban stormwater runoff by stepped bioretention systems. Ecol. Eng. 2017, 106, 340-348. [CrossRef]

100. Salata, K.-D.; Yiannakou, A. The Quest for Adaptation through Spatial Planning and Ecosystem-Based Tools in Resilience Strategies. Sustainability 2020, 12, 5548. [CrossRef]

101. Mill Creek Farm. Annual Report 2007. Available online: https://millcreekurbanfarm.org/sites/default/files/mill_creek_annual_ report_2007.pdf (accessed on 30 April 2021). 